I close with the hope that the students of political economy associated with this Section will see that this branch of their science, the economy of natural resources, so important and yet so much neglected, requires on their part a fuller and more careful consideration. $\quad$ B. E. FERNow.

Department of Agriculture, Washington, D. C.

CURRENT NOTES ON ANTHROPOLOGY (XII.).

'CARIB ART' AND ITS SIǴNIFICANCE.

When Von Den Steinen went among the Carib tribes of southern Brazil he was surprised to find himself called by them a ' Carib,' until he found the word means 'a stranger' (literally 'not like us'). It is, and long has been, a term used extremely vaguely. There are tribes in Central America called Caribs, who are no more allied to the Caribbean stock than are the Iroquois. In fact, there was not a single tribe of the stock in North America anywhere at the time of the discovery.

' Carib art' has been alleged to have left its traces in Florida and in the Greater Antilles; but the curvilinear decorations, the little clay images, and the broad, roughflaked arrow heads, asserted to be evidence of Carib work, have yet to be shown to be peculiar to that stock. In a recent pamphlet written by Mr. J. J. Quelch, curator in charge of the British Guiana Museum at Demerara, he mentions a number of such objects found on the Puruni River and the east coast, which he inclines to attribute to the Caribs, though historically they did not live in that region. Other relics were a small plate of gold, neat quartz beads, perforated, granite plates, pots and polishers and pottery with highly wrought figures of men and animals. These certainly suggest a nation to the west of the locality, but not necessarily Carib. That name should now be confined to the members of the well-marked linguistic stock which we now know so well through the admirable studies of Von Den Steinen and Lucien Adám. It is in no wise synonymous with 'Antillean,' as some have employed it. SYPHILIS AND LEPROSY IN ANCIENT AMERICA.

As a question in the history of disease, as well as having some archæological bearings, the presence of syphilis and leprosy in America before the discovery has deservedly attracted the attention of investigators.

The latest contribution to the subject is by Dr. Albert S. Ashmead, in a series of articles in the Journal of the American Medical Association, reprinted in pamphlet form. He has had the good idea of studying the ancient pottery for representations of persons afflicted with these deforming diseases, and his results are quite remarkable. $\mathrm{He}$ finds in the mound pottery of the United States, and especially in the ceramics of Peru, numerous figures of persons with their faces or members marred by some erosive disease, akin to, if not identical with, those mentioned. His conclusions are that both prevailed in different parts of America in pre-Columbian times; but that the deformations represented are more likely to be lupoid or syphilitic than leprous, without, however, excluding the possibility of the latter.

$\mathrm{He}$ does not consider that the presence of these diseases on the American continent would necessarily point to an extra-American source. We know too little of their etiology to justify the construction of theories in that direction; but it enables us better to understand the significance of many of the specimens in our museums.

$$
\text { PREHISTORIC BOTANY. }
$$

The American ethnologist, Charles Pickering, devoted the last fifteen years of his life to a vast work intended to show the early history and migrations of the human species by the distribution and cultivation 
of plants. Though left incomplete, it is a storehouse of information and suggestion.

Since then, prehistoric science has taken a long stride, and that branch of it devoted to the study of the vegetation which surrounded primitive man and his early culture-plants has not been neglected. We have but to remember what a conspicuous feature it is in the mooted question of the origin of the Aryans to see the value attached to it by thoughtful students.

In America, Dr. Harshberger, of the University of Pennsylvania, has contributed a searching study to maize, and others have traced the archæologic history of tobacco, mandioca, etc. A work which has just appeared in Europe from the competent pen of Dr. George Buschan takes up the cultivated and useful plants found in the prehistoric sites of the old world, both Europe and Asia (Vorgeschichtliche Botanik der Cultur und Nutzpflanzen der Alten Welt, auf Grund Prähistorischer Funde, J. U. Kern, Breslau, 1895). He has prepared for it by a ten years' study of the collections in various museums and in private hands, and has received the aid of most of the eminent archæologists of Europe. His results enable the student for the first time to estimate correctly the value and meaning of much of the material collected.

\section{G. Brinton.}

University of Pennsyluania.

CURRENT NOTES ON PHYSIOGRAPHY (XV.).

LAKES IN THE AUSTRIAN ALPS.

An atlas of the lakes in the Austrian Alps, prepared under the direction of Professors Penck, of the University of Vienna, and Richter, of the University of Graz, begins with a folio on the Lakes of the Salzkammergut, sounded by Simony and drawn by Mullner, and lately published by Hölzel, of Vienna. The text by Mullner will' constitute a number of Penck's Geographische Abhandlungen, to be issued shortly. A second number of the atlas will be by Richter, concerning the more eastern Alpine lakes. The eighteen maps now published are on a scale of $1: 25,000$; the land tinted in two or three shades of buff, the water in several shades of blue. The land has contours, generally at 20-meter interval; the water has the original sounding and the conjectural contours for every ten meters. Numerous true scale sections are added.

In this connection mention may be made of the atlas of French lakes by A. Delebecque, published by the French Ministry of Public Works, 1892-93 (Paris, Baudry), with maps on scales of $1: 10,000$ and 1 : 20,000 , for which a text is announced as forthcoming. The land surface is here left blank.

LOFTY BALLOONING IN GERMANY.

THe scientific skill of the Germans in lofty ballooning is only exceeded by the height of their ascents. The 'Cirrus,' fitted with automatic meteorological instruments and despatched without an observer, reached heights of $16,325 \mathrm{~m}$. above sea level on July 7, and 18,500 m. on September 6, 1894; the minimum recorded pressures being 85 and $59 \mathrm{~mm}$., and temperatures, $-53^{\circ}$ and $-67^{\circ} \mathrm{C}$. It is thought that these extremely low temperatures are nevertheless not so low as they should have been; the mechanical aspiration for the thermometer being regarded as insufficient. The heights are calculated with careful regard to temperature, thus making them less than the values that would be given by rough calculation, such as has been used by certain other aëronauts.

The 'Phœnix' carried Gross and Berson to a height of $7,930 \mathrm{~m}$. on May 11,1894 ; but this altitude was much exceeded by the ascent of Berson alone on December 4, to $9,150 \mathrm{~m}$. above sea level, where the temperature was $-47.9^{\circ} \mathrm{C}$. Berson prepared himself for this extraordinary flight by a good 